\title{
ALEXANDER AND THE \\ CULTURAL REFOUNDING OF AMERICAN SOCIOLOGY
}

\author{
Fuyuki Kurasawa
}

\begin{abstract}
This paper considers and evaluates Jeffrey Alexander's strong program in cultural sociology, which represents an exercise in paradigm formation and an ambitious attempt to refound American sociology along interpretive lines. Cultural sociology is assessed according to four axes, namely its social constructivist epistemology, culturalizing methodology, analytical realism, and internal and external positioning. In addition to discussing the accomplishments and limitations of cultural sociology in all these areas, the paper indicates ways to strengthen it by setting it in conversation with other and more explicitly critical currents of thought.
\end{abstract}

KEYWORDS critique - culture - interpretation • social constructivism • sociology

\section{SETTING THE SCENE}

Having entered the third century of its disciplinary existence, sociology finds itself in the midst of an identity crisis. Indeed, if it could speak, its first question to us would likely be 'what exactly am I?' On the one hand, the natural scientific ambitions that animated some of its founders continue unabated in certain circles, where the dream of a science of society is eagerly pursued via the development and application of ever more refined quantitative measurements techniques and comprehensive models purporting to reveal the true functioning of particular institutions or phenomena and, thus, to produce knowledge applicable across settings and periods. On the other hand, the rise and rapid expansion of cultural studies over the past few decades has meant that sociology has lost part of its raison d'être and effective analytical monopoly over one of its prime objects of study - culture. In

Thesis Eleven, Number 79, November 2004: 53-64

SAGE Publications (London, Thousand Oaks, CA and New Delhi)

Copyright (C) 2004 SAGE Publications and Thesis Eleven Pty Ltd

DOI: $10.1177 / 0725513604046956$ 
certain English-speaking intellectual environments (the UK, Australia, Canada), sociology could become a subfield of its rebellious stepchild, which appears to be more in tune with the contemporary preoccupations and interests of academic and lay audiences alike.

Predictably, sociologists have reacted to this identity crisis by splitting into two camps, either reaffirming the 'hard' scientific core of the discipline or welcoming cultural studies' 'soft' makeover of it as a humanistic enterprise. But must skepticism toward one of these options invariably lead to the other, and more importantly, are these the only alternatives available to us as sociology attempts to find itself anew?

It is in light of such considerations that the significance of Jeffrey Alexander's latest book, The Meanings of Social Life (2003), comes into its own. Probably still best known for his monumental Theoretical Logic in Sociology (1982), one of the landmarks of American sociological theory in the second half of the 20th century, Alexander has more recently embarked upon a project of inventing, refining and advancing what he terms - here taking a cue from science and technology studies - the 'strong program' in cultural sociology. The results of this ongoing endeavour are collected in The Meanings of Social Life, which contains pieces written (two of them with Philip Smith) in this cultural sociological vein over the past two decades. What needs to be stressed is the disciplinary radicalism of what Alexander is advocating, especially in the American context. The strong program is not a form of Kuhnian 'normal science', the pouring of new wine in the old bottles of already existing frameworks of the sociology of culture and cultural studies - both of which, he believes, are afflicted by economistic and institutionalist overdetermination. Rather, it amounts to an exercise in paradigm formation, and thus nothing less than an argument for the complete refounding of the American sociological undertaking by 'culturalizing' it through and through.

While Alexander is catholic in the influences upon which he draws, cultural sociology amounts to a late Durkheimian project that carries forward The Elementary Forms of Religious Life's pioneering insights into the symbolic dimensions of collective representations and ritual action (Durkheim, 1995 [1912]). As such, both the interpretive and structuralist components of Durkheim's magnum opus frame Alexander's own theoretical paradigm, 'structural hermeneutics'. At one level, cultural sociology represents the latest manifestation of the interpretive turn launched by figures such as Geertz and Taylor in the Anglo-American human sciences during the 1960s and 1970s, a turn that has positioned meaning at the heart of social life; human beings are sense-making creatures who inhabit a universe of signs and discourses, the interpretation of which contributes to the constitution of that very universe. At another level, cultural sociology incorporates into its fold elements of structuralist and semiotically-inspired literary criticism (Frye, Barthes, etc.) and social anthropology (Sahlins, Douglas, Lévi-Strauss). This 
enables Alexander to demonstrate that, instead of being random or fully spontaneous phenomena, symbolically and discursively mediated significations are congealings of social interactions and institutionalized processes structured by and themselves structuring regularized meaning-producing scripts and typifications: narrative frames and genres, and binary codes (good/evil, pollution/purity, sacred/profane, etc.). Holding structural hermeneutics together is a performative and dramaturgical vision of social life that, here again, builds upon literary and anthropological sources (Burke, Turner) to underscore the cultural significance of ritual action and mythical conventions.

But The Meanings of Social Life is not content to breathe the rarified air of 'high theory'. On the contrary, it wears its theoretical armature lightly as Alexander opts for what he calls a 'cultural pragmatics' that works out and elaborates the different strands of his approach on the spot, in and through a series of detailed empirical studies that make up the core of the book. Therefore, aside from the first, more programmatic chapter, cultural sociology is brought to bear on wide-ranging issues - the Holocaust, Watergate and the Iran-Contra Affair, technology, collective trauma, evil, intellectual representations of the present, and so on and so forth. In giving them a cultural sociological treatment, which includes detailed research of newspaper, magazine and television archives, Alexander is able to unearth the secret lives of such topics, the complexes of affects, myths and beliefs that make them real for us and matter to us.

Although a chapter-by-chapter description of the book's substantive contents is well beyond the scope of this paper, I want to pull out four axes that cut across The Meanings of Social Life and allow us to simultaneously clarify and interrogate the cultural sociological venture. Moving outward from the more specific to the more general, these features are: (1) social constructivism; (2) culturalism; (3) analytical realism; and (4) intra- and interparadigm self-understanding.

\section{SOCIAL CONSTRUCTIVISM: WEAK OR STRONG?}

The first aspect of cultural sociology that warrants attention is its epistemological stance, a social constructivism that is equally suspicious of both objectivism and naturalism. Alexander contests the object/subject dichotomy that forms the basis of objectivist knowledge claims, with their positing of a world of things that exists independently of our perceptions and understandings of it. But to paraphrase a Derridean quip that has become somewhat of a social constructivist rallying-cry, there is nothing outside the text, if by 'text' we mean the discursive schemes through which the world becomes meaningful to us. Extending this line of thinking in a sociological direction, Alexander advocates a total culturalization of social analysis in order to liquidate the 'naturalistic fallacy' that ontologizes meaning 
- that is to say, the belief that the latter is intrinsic to an object from which it radiates outward to reach subjects who react to it as an already existing reality. Pace the journalistic and objectivist truism, facts do not speak for themselves or, as Alexander (2003: 177) pithily phrases it à la Beauvoir, '[s]candals are not born; they are made'. For cultural sociology, the meaning of an event or phenomenon is constructed over time through three processes: narrative framing (how are the various elements of this event or phenomenon regrouped, positioned and incorporated into a larger plotline or story?); symbolic coding (how is it classified according to binary affective and moral codes?); and weighting (what resources are brought to bear in its construction and dissemination?). Because persons, groups or occurrences must be coded and become perceived as evil, polluted or sacred, rather than being inherently so, the attribution of specific emotion- and value-laden signifiers to any social signified is a cultural process of meaning construction. In chapters of The Meanings of Social Life devoted to the Holocaust and the Watergate crisis, among others, Alexander supplies telling illustrations of such ideas. Cultural sociology's denaturalizing drive even extends to the realm of the affective, which has been poorly served by the proclivity to view it as a self-evident and pre-social reality.

Where Alexander's epistemological position is on shakier ground is in its occasional slippage between what I would call strong and weak versions of social constructivism. According to the strong version, reality does not exist as such; only our interpretations and representations of it are real, and thus constitutive of the world around us. In other words, how we describe and make sense of the social is the social in toto. Questioning this cognitivist hubris does not demand that we fall in line with objectivist or crudely materialist arguments, for a more defensible weak version of social constructivism allows us to argue that reality is discursively and symbolically mediated, yet only partly created out of representational and interpretive processes. That facts do not speak for themselves does not mean that they are entirely made by culture - rather, they are made to speak by it. The range of correspondence between symbolic signifiers and social referents is certainly wide, though not completely arbitrary, and these signifiers are not in and of themselves the only forces constitutive of the real. This crucial distinction, between giving social life meaning (weak social constructivism) and giving it existence (strong social constructivism), is one that Alexander does not consistently maintain or make explicit.

\section{THE CULTURIZING MOVE}

Flowing out of this epistemological discussion is the strong program's defence of the analytical autonomy of culture vis-à-vis other spheres of social life; the cultural domain has immanent dynamics of discursivity and symbolization that need to be grasped for their own sake. This culturalist position 
has the merit of immunizing social analysis against economistic and institutional reductionism, although the proposed cure may not be much better than the ills it is meant to address. Cultural sociology reverses culture's standing from that of a dependent to an independent variable, an overcompensating inversion that veers dangerously close to a kind of culturalism that, by privileging one dimension of society over all others, suffers no less from reductionism than its economistic or social structuralist counterparts. The benefits of Alexander's approach, its enabling of immanent interpretations of the sense-making content, narratives and symbolic patterns of cultural life, may also be a drawback in that it does not sufficiently ponder how such cultural structures interact with key social institutions, notably the state and the market. To my mind, the issue of causal primacy, of dependence or independence of any sphere of social life in relation to others (whether it be culture, the economy, or the state) and of relative or absolute autonomy, is rather misplaced. Better to think about and examine the interdependence and interweaving of all of these arenas, their mutual constitution in the creation of a complex and overlapping whole that we call society.

Wisely, The Meanings of Social Life declares itself in favour of overcoming the cultural/material dichotomy that plagues most kinds of sociology, something Alexander aims to accomplish by way of the notion of 'cultural structure'. However, I would term his understanding of structure a 'soft' one, in that it consists of narrative frames and binary symbolic codes enabling or constraining action via their internalization by subjects; cultural structures structure meaning. The 'hard' aspect of cultural structures, the hierarchical organization of the field of social action and meanings through asymmetrical access to and knowledge of discursively mediated economic, political and symbolic resources and strategies, tends to be given short shrift. ${ }^{1}$ There is no doubt that political economists and institutionalists ought to acknowledge the cultural dimension of the socio-economic and political realms more readily than they have in the past, for culture is not merely a matter of power. Equally necessary, though, is cultural sociology's greater recognition of the socio-economic and political aspects of cultural beliefs and processes, so as to avert turning power into a matter of culture (in the sense of framing, coding, and symbolization). To be fair, Alexander does anticipate some of these concerns by introducing ideas of weighting and control of the means of symbolic production into cultural sociology (esp. 2003: 32-33), but they are somewhat under utilized or inattentive to the ways in which relations of power and mechanisms of domination circulate through contemporary society. To argue that such relations and mechanisms function symbolically is not the same as giving them adequate analytical attention. Hence, one wishes that cultural sociology's decentring of 'hard' cultural structures would still allow more space for them, and by extension, for a consideration of the interpenetration of and interaction between various modalities of power (symbolic, socio-economic, political, and so on). 


\section{GOODBYE TO ALL THAT WISHFUL THINKING}

The blending of social constructivist epistemology and culturizing methodology has given birth to one of cultural sociology's most commendable contributions, what could be identified as its analytical realism. Alexander intends this realist vantage-point to act as a corrective to the prevalence of normativism in the human sciences, an analytical idealism that largely because of the influence of neo-Kantian philosophical and political theoretical currents (Habermas, 1996; Rawls, 1971) - conflates what is with what ought to be and is thereby willfully blind to the Janus-faced and morally nuanced character of social life. Far from being abnormal or deviant occurrences to be merely wished away or progressively eliminated over time, pathological and devalued phenomena (evil, pollution, etc.) are integral to culture to the extent that their binary opposites (goodness, purity) would be meaningless without them. Any model that disavows the moral dualism and complexity of society cannot account for the social construction of its own normative vision, nor appreciate the actual difficulties in realizing the latter. By contrast to the belief that civil society is an intrinsically emancipatory institution that nurtures only enlightened publicity and collective virtue, The Meanings of Social Life treats it as a cultural ensemble moulded by discursive structures and processes of symbolic coding. What matters, from a cultural sociological perspective, is less the normative worth of civil society than an understanding of the binary codes and narrative genres that organize and give meaning to public discourse by citizens.

If he is critical of normativism, Alexander is no less skeptical of an excessive cognitivism that supports the hyper-rationalist tale according to which modernization filters out of so-called 'irrational' remnants of cultural life - processes of demagification, secularization and instrumental rationalization leading to the death of myth, sacredness and affectivity. Drawing inspiration from the Durkheimian School's pioneering efforts to integrate sociological and anthropological knowledges a century ago, cultural sociology performs an 'ethnologization' of Euro-American societies that engages with modern modes of thought and action as mythical constructs and ritual performances involving the heart and the mind, the sacred and the profane, the pure and the polluted, as well as good and evil. To be meaningful to individuals and groups, modern culture cannot but evoke emotional, mythical and sacred resonances. Even the seemingly most cognitive and abstract of domains is replete with such significations, as Alexander contends in a chapter on cultural narratives about computer technology. ${ }^{2}$ Elsewhere in the book, the democratic foundation of American civil society is shown to be a living practice and faith that must be periodically affirmed and reaffirmed through sacred public rituals, ceremonies and binary-coded discourses, which affectively and morally purify the body social by expelling counter-democratic tendencies and thereby reinstitutionalizing the 
preeminence of certain values and procedures during and after a polluting political crisis such as Watergate or the Iran-Contra scandal. This ethnologizing viewpoint enables Alexander, in the book's encyclopedic last chapter, to put into myth the diagnoses of the present circulating in intellectual circles over the past few decades by unearthing their rhetorical patterns and narrative typifications. As he demonstrates, the widespread acceptance of any characterization of our predicament, or lack thereof, cannot simply be explained by referring to its analytical strengths, its fit with and capacity to accurately reflect socio-cultural reality. Fundamentally, epochal diagnoses are sense-making devices whose levels of intellectual recognition also depend upon evoking their audiences' existential, political, affective and normative convictions, that is to say, their hopes, fears, dreams, beliefs and values, as well as their visions of the past, present and future.

\section{CARVING OUT AN ALTERNATIVE SPACE}

In the final section of this paper, I want to return to the question of cultural sociology's relationship to other social scientific approaches. As previously mentioned, The Meanings of Social Life is in the business of paradigm creation and, as such, must rhetorically establish the analytical superiority of cultural sociology vis-à-vis rival frameworks. Given this requirement, the book has a tendency, notably in the manifesto-like opening chapter and in remarks scattered elsewhere, to rely on a 'strawman effect' that caricatures and quickly discards such other frameworks instead of seeking to establish a conversation with them. At least four instances of what could be considered a missed opportunity stand out in this respect. Foucaultian theory is the first to fall through the cracks, for if Alexander's remark that much of the literature on governmentality is latently structuralist in its use of the idea of discourse rings true for the most part, many other Foucaultians have produced rich, interpretively driven socio-historical studies of facets of modern culture (Castel, 1995; Rabinow, 1996, 1999). Secondly, Alexander's rather caustic interpretation of Adorno's 'culture industry' thesis (Horkheimer and Adorno, 1972: 120-167) and of Habermas' (1987) notion of colonization of the lifeworld by the system undervalues the Frankfurt School's potential contributions to cultural sociology. Upon closer examination, Adorno's corpus reveals a more nuanced understanding of culture (albeit one that asserts a high/low distinction), whereas Habermas' colonization scenario is less about how an instrumentally rationalist juggernaut is generating a normative vacuum than the kinds of rationality and social order we moderns ought to pursue. Moreover, Alexander completely overlooks the writings of the Frankfurt School's 'cultural wing', such as those of Kracauer $(1995,1998)$ and Benjamin $(1973$, 1999). The latter's iconic and quasi-reverential status in cultural studies should not obscure the fact that both he and some of his followers have 
persuasively grappled with the mythological and affective dimensions of modern existence, and this without reverting to economism. ${ }^{3}$

The third tradition on which Alexander prematurely closes the door is that of the Birmingham School. It is undoubtedly important to recognize, as he rightly indicates, that certain early Birmingham School studies adopted an instrumentalist and ideological conception of culture as they became tangled up in the Althusser-Foucault-Lacan-Gramsci theoretical vortex of the late 1970s and early 1980s. However, Alexander paints with too broad a brush and consequently tars all in this constellation with the accusation of immiserating cultural interpretation. It is difficult to see how his criticisms apply to the Birmingham School's English Marxist progenitors (Thompson, 1980; Williams, 1958), or indeed to the recent work of its contemporary representatives (Gilroy, 1994, 2000; Hall, 1990, 1991), who assuredly give culture its due as a structured and structuring networks of meaningful social relations. Finally, cultural sociology does not do justice to a French stream of critical analysis of modern culture, whether in Lefebvre's (1995) humanist guise or Bourdieu's (1984, 1990) reflexive one. In light of Alexander's (1995) previously published and scathing critique of Bourdieu, it is not much of a stretch to see him as the bête noire of The Meanings of Social Life. What I want to suggest, nevertheless, is that the two antagonists need each other in ways that have yet to be recognized, for their standpoints on culture can be viewed as complementary rather than fundamentally incommensurable. On the one hand, there is little doubt that Bourdieu's work is hermeneutically insensitive, since it advances an externalist stance on culture that hones in on how 'hard' socio-economic and symbolic cultural structures shape and are shaped by practices and belief systems, which are themselves situated within social fields that refract relations of domination and subordination. Further, Bourdieu is not concerned with the immanent meaning of, say, a work of art, but rather in how a particular interpretation of this meaning fits into the broader field of aesthetic judgement that is related to and reflects the dynamics of other spheres of social life. On the other hand, to bring back a point made earlier, Alexander's focus on the 'soft' aspect of cultural structures tends to underplay its interaction with its 'hard' counterpart, the ways in which symbolic codes and narrative genres exist in a relation of mutual causality with political and socio-economic forces. As a result, and in an almost symmetrically converse manner when compared to Bourdieu, cultural meaning is granted too much autonomy. Yet the gulf is not impassible: the alliance of Alexander and Bourdieu brings the 'hard' and 'soft' dimensions of culture onto a horizontal plane where the symbolic and the material can, at long last, meet as equals.

Keeping in mind this last point, we can turn our attention to cultural sociology's theoretical undergirding, 'structural hermeneutics'. While the wealth of eclectically diverse influences Alexander melds together and synthesizes is to be welcomed, it would have been appropriate to supply a more 
sustained and systematic working out of the affinities, points of tension and possible contradictions between such varied streams of thought. It may well be that 'structuralism and hermeneutics can be made into fine bedfellows' (Alexander, 2003: 26), but given that they have historically been defined as antagonists, greater theoretical demonstration of a claim of analytical harmony would have been more convincing. In its purist heyday, structuralism saw itself as a revolutionary movement in the human sciences that would entirely dispense with the previously dominant phenomenological and hermeneutical emphasis on subjectivity, experience and meaning. Affirming the primacy of universally reproduced deep patterns and mechanisms, structuralists celebrated the conquest of form over content and the death of the subject; discourses speak us and texts write us. Since then, of course, many authors hailing from poststructuralist and interpretive camps have claimed to discover a happy medium between hermeneutics and structuralism, yet most have done so without transcending the oppositions of form and content, structure and agency, or historical reproduction and change. Scattered throughout the book are tantalizing clues as to how one might begin to accomplish such a task, although much of the theoretical groundwork remains to be done. How, for instance, does cultural sociology come to grips with a non-voluntarist conception of socially creative collective action (Castoriadis, 1987; Joas, 1996), according to which individuals and groups may invent and institute novel modes of practice and thought that overturn or subvert familiar or regularized narrative genres and symbolic codes? Is binary coding the only kind that exists, and if so, how do we explain the persistence of, and even the quest for, forms of ambivalence and ambiguity that resist dichotomization, so that the same person may interpret a specific event or phenomenon as an inseparable complex of the pure and the polluting, the sacred and the profane, or the good and the evil? Tackling questions of this sort is a call to further reflection on structural hermeneutics rather than to pursue theoretical model building for its own sake.

Last but not least, cultural sociology could have been bolstered by greater elaboration of its connection to the task of critique of the established social order. Alexander is attuned to this issue, as is evident in certain revealing passages from the book. ${ }^{4}$ And yet, while eschewing morally idealistic delusions about social life, his analytical realism often embraces a kind of normative agnosticism that elects to study the formal cultural structures that socially construct a phenomenon or event, instead of the effects it has on hierarchical social relations and the mechanisms of power through which it operates. Hence, by virtue of denaturalizing and reinterpreting many taken for granted social processes, cultural sociology excels in analytical terms, while falling somewhat short normatively; the purpose of culturalizing everything, its critical thrust, is consequently blunted. The final chapter of The Meanings of Social Life, written in the wake of Marx's 11th thesis on Feuerbach, closes with the declaration that 'the task of intellectuals is not only to 
explain the world; they must interpret it as well' (Alexander, 2003: 228). Granted, if two caveats are kept in mind: firstly, that critique need not mean a dismissal of interpretation in favour of an obsessive preoccupation with power or a delusionally self-aggrandizing pose of intellectual militancy (knowledge in the service of revolution); and secondly, that regardless of whether we speak of explaining, interpreting or changing the world, clearheaded analysis and normative commitment can go hand-in-hand.

\section{CONCLUSION}

With The Meanings of Social Life, Alexander has boldly staked his claim for the internal transformation of American sociology. The reformist cloak which his project wears should not allow us to underestimate its radical character. Cultural sociology is not content to tinker at the edges of the discipline, for it demands the latter's reconstruction from the ground up as an interdisciplinary, interpretively centred, theoretically informed and empirically nimble field of social inquiry. And those looking at this new direction from the outside, from the vantage-point of other disciplinary realms, could learn more than a thing or two from Alexander's culturalizing strong program.

Crisis may well have become the perpetual and defining state of the human sciences in this new millennium, something that is not altogether unwelcome. Indeed, whether it be in history of art or of academic work, periods of self-questioning tend to foster a healthy dose of introspection and openness to the unexpectedly new, as well as sudden bursts of creativity and innovation. One can hope that, as it continues to participate in this vast movement of rethinking and renewal, cultural sociology will seek out opportunities to dialogue with other, more explicitly critical currents of social analysis. If it does so, the strong program holds the promise of offering us what has hitherto proved to be an elusive gift: a non-reductionist cultural critique.

Fuyuki Kurasawa teaches sociology at York University in Toronto and is a Faculty Associate of the Yale Center for Cultural Sociology. He is the author of The Ethnological Imagination: A Cross-Cultural Critique of Modernity (University of Minnesota Press, 2004). [email: kurasawa@yorku.ca]

\section{Notes}

1. It is important to keep in mind that I intend 'soft' and 'hard' to refer to attributes that are internal to cultural structures, rather than what Alexander rightly identifies as the sociology of culture's problematic model of a 'soft' (and thus dependent) cultural life and a 'hard' (that is, causal and independent) social structure.

2. This chapter of The Meanings of Social Life, entitled 'The Sacred and Profane 
Information Machine', curiously overlooks the vast field of science and technology studies, which has put forth detailed and compelling analyses of the cultural and mythological foundations of techno-science.

3. For a fascinating study that draws on Benjamin in this way, see Buck-Morss (2000).

4. For example, he states that 'only if cultural structures are understood in their full complexity and nuance can the true power and persistence of violence, domination, exclusion, and degradation be realistically understood' (Alexander, 2003: 7).

\section{References}

Alexander, J. C. (1982) Theoretical Logic in Sociology, 4 vols. Berkeley: University of California Press.

Alexander, J. C. (1995) 'The Reality of Reduction: The Failed Synthesis of Pierre Bourdieu', in Fin de Siècle Social Theory: Relativism, Reduction, and the Problem of Reason, pp. 128-217. London and New York: Verso.

Alexander, J. C. (2003) The Meanings of Social Life: A Cultural Sociology. New York: Oxford University Press.

Benjamin, W. (1973 [1955]) Illuminations, ed. H. Arendt and trans. H. Zohn. London: Fontana.

Benjamin, W. (1999) The Arcades Project, ed. R. Tiedemann, trans. H. Eiland and K. McLaughlin. Cambridge, MA: Belknap/Harvard University Press.

Bourdieu, P. (1984 [1979]) Distinction: A Social Critique of the Judgement of Taste, trans. R. Nice. Cambridge, MA: Harvard University Press.

Bourdieu, P. (1990 [1980]) The Logic of Practice, trans. R. Nice. Cambridge: Polity.

Buck-Morss, S. (2000) Dreamworld and Catastrophe: The Passing of Mass Utopia in East and West. Cambridge, MA: MIT Press.

Castel, R. (1995) Les métamorphoses de la question sociale: une chronique du salariat. Paris: Fayard.

Castoriadis, C. (1987 [1975]) The Imaginary Institution of Society, trans. K. Blamey. Cambridge: Polity.

Durkheim, E. (1995 [1912]) The Elementary Forms of Religious Life, trans. K. E. Fields. New York: Free Press.

Gilroy, P. (1994) The Black Atlantic: Modernity and Double Consciousness. Cambridge, MA: Harvard University Press.

Gilroy, P. (2000) Between Camps: Nations, Cultures, and the Allure of Race. Harmondsworth: Penguin.

Habermas, J. (1987 [1981]) The Theory of Communicative Action, Vol. II: Lifeworld and System, trans. T. McCarthy. Boston: Beacon Press.

Habermas, J. (1996) Between Facts and Norms: Contributions to a Discourse Theory of Law and Democracy, trans. W. Rehg. Cambridge, MA: MIT Press.

Hall, S. (1990) 'Cultural Identity and Diaspora', in J. Rutherford (ed.) Identity: Community, Culture, Difference, pp. 222-237. London: Lawrence \& Wishart.

Hall, S. (1991) 'The Local and the Global: Globalization and Ethnicity', in A. D. King (ed.) Culture, Globalization and the World-System: Contemporary Conditions for the Representation of Identity. Binghamton: Department of Art and Art History, State University of New York at Binghamton. 
Horkheimer, M. and T. W. Adorno (1972 [1944]) Dialectic of Enlightenment, trans. J. Cumming. New York: Continuum.

Joas, H. (1996 [1992]) The Creativity of Action, trans. J. Gaines and P. Keast. Cambridge: Polity.

Kracauer, S. (1995 [1963]) The Mass Ornament: Weimar Essays, ed. and trans. T. Y. Levin. Cambridge, MA: Harvard University Press.

Kracauer, S. (1998 [1930]) The Salaried Masses: Duty and Distraction in Weimar Germany. London and New York: Verso.

Lefebvre, H. (1995 [1962]) Introduction to Modernity, trans. J. Moore. London and New York: Verso.

Rabinow, P. (1996) Essays on the Anthropology of Reason. Princeton, NJ: Princeton University Press.

Rabinow, P. (1999) French DNA: Trouble in Purgatory. Chicago: University of Chicago Press.

Rawls, J. (1971) A Theory of Justice. Cambridge, MA: Harvard University Press.

Thompson, E. P. (1980 [1963]) The Making of the English Working Class. Harmondsworth: Penguin.

Williams, R. (1958) Culture and Society 1780-1950. Harmondsworth: Penguin. 